\title{
A SURVEY OF WEED FLORA IN CROP FIELDS OF AHEMADNAGAR TEHSIL (M.S.), INDIA
}

\author{
1Jayashri Mulay, 2Jayesh Salve*
}

${ }^{1}$ New Arts, Commerce and Science College Ahemadnagar, (MS), India.

${ }^{2}$ Botany, Pratap College, Amalner, Dist. Jalgoan, (MS), India

Corresponding Author Email: salvejayesh777@gmail.com

\author{
Communicated: 26.07.2020
}

Revision : $1.08 .20 \& 27.8 .2020$ Accepted: 10.08 .2020

Published: 30.09 .2020

\begin{abstract}
:
Weeds cause serious ecological problems. Weeds contribute significantly to reduced crop yield and quality even though several management programs have been used. The present study was conducted to explore the weed flora in crop fields of Ahemadnagar tehsil in Maharashtra state. The study was based on extensive and intensive field surveys made in different months of Kharif and Rabi seasons during 2010-2012. Crop fields from the study area were surveyed for the weed population studies. A total of 85 angiospermous weeds were identified. Out of 85 weed species, 68 were dicots and 17 were monocots. According to the frequency, three dominant weed species were found to be Parthenium hysterophorus, Ageratum conyzoidis and Euphorbia geniculata.
\end{abstract}

Key words: - Frequency, Most abundant, Population studies, Survey, Ahemadnagar tahsil, Weed flora.

\section{INTRODUCTION:}

Weeds are the plants, which grow where they are not wanted. Weeds differ from other plants in being more adaptive and having peculiar characteristics that make them more competitive (Dangwal et al.2010). They are non-indigenous plants that can invade or negatively alternative plant communities (Muhammad et al., 2009). Weeds represent one of the greatest limiting factors to efficient crop production. They Weeds cause greater economic losses on agricultural lands than all other pests combined (Kremer and Kennedy 1996). These weeds effectively compete with the crop for nutrients, water, space and reduce the yield ranging from 12 to51 \% (Rao and Singh, 1997; Mukharjee and Singh,2005; Halder and Patra, 2007). Weeds also serve as reservoir for plant pathogens that may cause significant loss in crop production. They may also support populations of non-native animals and microbes and hybridize with native species subsequently altering the gene pools (Mahanta et al,2007). The invasive weeds disturb the structure and composition of the native vegetation and $a$ as result create pressure on the food chain and web of the ecosystem (Pysek and Richardson, 2007; Bais et al., 2003; Pimentel et al., 2000). Weeds establish mutualistic relationship with insect pollinators to successfully invade new area (Jesse et al., 2006; Morale and Aizen, 2006) affecting numerous ecosystems. Certain weeds release into the soil the inhibitors or poisonous substances which are harmful to the plants, human beings and live-stocks. Many weed species are difficult to kill (Farkas,2006). They increase the expenditure on labour and equipment, render harvesting difficult, and reduce the quality and marketability of agricultural produce. Agricultural crops serve a source for number of industrial products, besides their major use for human food. The average per hectare yield of these crops in 
India is less as compared to other advanced countries due to many factors like lack of irrigation, availability of fertilizers and other ecological factors. Out of which the problem of weeds is the major barrier in the loss of production. Weed flora and its composition in a crop is influenced by the type of cultivation, time or season of cultivation, soil type, soil $\mathrm{PH}$, climatic conditions, cultivation practices like irrigation, tillage systems

\section{STUDY AREA}

The Ahemadnagar district is located between $18^{\circ} 02^{\prime} \mathrm{N}$ lat., $19^{\circ} 09^{\prime} \mathrm{E}$ North latitude and $73^{\circ} 05^{\prime}$ and., $75^{\circ}$ 05' East longitude andis situated partly in the upper Godavari river basin and partly in the Bhima river basin It is largest district of Maharashtra occupying more or less the central position in the state and with an area of 17,413 sq. km. As regards the botanical explorations in Ahmednagar, several people have made notable contributions, such as Pradhan and Singh

(1999), Santapau (1951), Santapau and Irani (1962), most of these works resulted in enrichment of the Herbaria except few publications, like Shirke (1978). Hooker et al (1872-1897), Cooke (1909-1917) have recorded plants from Ahmednagar district in their publications. However, extensive work for the flora of the Ahmednagar district has been done by Pradhan and Singh (1999). In spite such an extensive works present investigation indicates that the plant wealth of Ahmednagar city area has not been given enough emphasis and needs more attention.

\section{MATERIALS AND METHODS}

The present ethno botanical survey was done during 2010-2012 in different villages of Ahemadnagar Old experience and tribal medicine men (Vaidya) were consulted to know about the use of various plants growing in their localities. Herbariums of the useful weeds were prepared and identification was done following standard literature (Singh et al, 2000 \&2001; Cooke, 1958; Pradhan and Singh, 1999). Herbarium specimens are deposited in the Botany Department Deogiri College, Aurangabad

\section{METHODOLOGY:}

The present study was conducted to find out the weed flora in crop fields (viz. Soybean, Rice, Maize, Jowar, Sugarcane and Wheat) of Ahemadnagar tahsil. The study was based on extensive and intensive field surveys. The weed survey was made by least count quadrat method (Misra, 1968) using $1 \mathrm{~m} 2$ quadrats. In each field, 5 quadrats were laid down and number of each species in quadrat was recorded. Weeds were then identified (Cooke, 1967; Yadav and Sardesai, 2002). Frequency, an important quantitative Curtis and McIntosh (1950). analytical parameter of weed species was determined as per Frequency percentage refers to the degree of dispersion of individual species in an area and usually expressed in terms of percentage occurrence. It was studied by sampling the study area at several places at random and recorded the name of the species that occurred in each sampling units. It is calculated by the equation:

Frequency $(\%)=$ Number of quadrats in which the species occurred X 100 / Total number of quadrats studied.

A list of twenty dominant weeds was prepared according frequency of their occurrences.

\section{RESULTS AND DISCUSSION:}

Total of 85 angiospermous weeds were identified. Out of 85 weed species, 68 were dicots and 17 were monocots. Family Asteraceae, Poaceae, Euphorbiaceae, Amaranthaceae and Malvaceae represented 
the weed genera. Total number of weeds was less in rabi season than kharif. During kharif season, on the basis of frequency most dominant weed species were Ageratum conyzoidis L $(52.10 \%), \quad$ Parthenium hysterophorus (49.50\%) and Euphorbia geniculata (47.20\%). The frequency of other weed species ranged from 11.8 to $39.8 \%$. During rabi season, the most abundant weeds were Parthenium hysterophorus (56.78\%), Ageratum conyzoidis L (44.90) and Euphorbia geniculate (36.40\%). Throughout the year, according to the frequency, three dominant weed species were found to be Parthenium hysterophorus, Ageratum conyzoidis and Euphorbia geniculata. Partenium hysterophorus L., most dominant weed in our survey is also known as congress grass, ragweed, Carrot weed, white top, star weed. Parthenium is a noxious weed native to tropical America. It has now spread in several tropical and subtropical parts of the world (Kohli et al., 2009). It was first reported in India in 1956 growing in the outskirts of Poona (Rao, 1956). Now, it has become one of the major and prominent weeds during the last two decades and is still continuing to spread in the urban as well as natural habitats. Parthenium weed has been reported from all regions of India. $P$. hysterophorus is an annual, erect herb, reaching a height up to $2 \mathrm{~m}$. The plant has a tap root system with a number of secondary and tertiary roots. The leaves are rhomboidal, dissected and arranged alternatively on the stem. The leaves and stem have small hair-like outgrowths called trichomes. The inflorescence in $P$. hysterophorus is capitulam type having creamywhite coloured flowers. The fruit of the plant is cypsela. The seeds are dark brown, very light in weight and often dispersed by means of air up to several kilometers (see plate-1). Parthenium weed is a prolific seed producer capable of producing up to 15,000 seeds per plant. Parthenium typically represent greater than 50 per cent of the total soil seed bank. Up to 400 million Parthenium seeds per hectare can be present in the surface soil compared to 1, 20, 000 native grass seeds. It is regarded as one of the worst weeds in the nation because of its invasiveness, potential for spread, and economic and environmental impacts. Parthenium weed negatively affects the primary agricultural production and also causes health problems in humans and animals. Contact with airborne pieces of dried plant material, pollen or even roots of Parthenium can cause the development of allergic reactions. The symptoms in humans include: severe contact dermatitis, allergic rhinitis, allergic bronchitis. Parthenium weed is also toxic to animals and produces pronounced skin lesions on all animals including horses and cattle, mouth ulcers with excessive salivation if eaten, eye irritation in working dogs and death due to rupturing and haemorrhaging of internal tissues and organs. Ageratum conyzoides, second most dominant weed in our survey is also known as Goat weed, Billygoat weed, Chicken weed or Whiteweed. Weed belongs to familyAsteraceae, Order-Asterales, Class-Eudicots, Subkingdom-Angiosperm and KingdomPlantae. The plant is known to have originated from tropical America and now spread to various tropical and subtropical parts of the world (Juliana et al.,2010). In India, it was introduced in 1860 as an ornamental plant (National Focal Point for APFISN, India, 2005). Later it escaped as a weed in various habitats throughout India. It is an annual branching herb which grows to approximately $1 \mathrm{~m}$ in height. The stems and leaves are covered with fine white hairs; the leaves are ovate and up to $7.5 \mathrm{~cm}$ long. The flowers are purple to white, less than $6 \mathrm{~mm}$ across and arranged in close 
terminal inflorescences. The fruits are achene and are easily dispersed while the seeds are photoblastic and often lost within 12 months. Viability of the seeds is often lost within 12 months (see plate-1). It is not eaten by men because of its bad odour, like a male goat and is named goat weed or billy goat weed. Ageratum conyzoides has bioactive activity that may have agricultural use, as shown by several research investigations in different countries. This plant is widely utilized in traditional medicine. It has been long known in herbal medicine as a remedy for diverse ailments. The weed have various pharmacological significance like antibiotic efficacy, analgesic effect in rats, antioxidative effect (Jagetia et al., 2003), hepatoprotective effects (Ita et al., 2009) and as a blood booster (Ita et al., 2007).Weed causes severe problems for farmers and ecologists because of its propagation potential. It

has been reported as host of many crop diseases. Weeds interfere with growth and production of crops and therefore exert significant ecological and economic impacts. It also produces health hazards to humans and animals. Ingestion of $A$. conyzoides can cause liver lesions and tumors (Fu et al., 2002). Mass poisoning incident in Ethiopia was as a result of contamination of grain with $A$. conyzoides.

\section{REFERENCES:}

Ashok, K.B.S., Lakshman, K., Jayaveea, K.N., Sheshadri, S.D., Saleemulla, K., Thippeswamy, B.S., Veerapur, V.P. (2010): Antidiabetic, antihyperlipidemic and antioxidant activities of methanolic extract of Amaranthus viridis Linn inalloxan induced diabetic rats. Exp. Toxicol. Pathol., Available online 18 July, 2010.
Bais, H.P., Vepachedu, R., Gilroy, S., Callaway, R.M. and Vivanco, J.M. (2003): Allelopathy andexotic plant invasion: From molecules and genes to species interactions. Sci., 301: 1377-1380.

Cooke, T. (1967): The Flora of the Presidency of Bombay, BSI, Calcutta. (Repr. ed.) vol. I 111.

Curtis, J.T. and McIntosh, R.P. (1950): The interrelations of certain analytic and synthetic phytosociological characters. Ecol. 31: 434-455.

Dangwal, L.R., Singh,A., Singh ,T. and Sharma C.(2010): Effect of weeds on the yield of wheat crop in Tehsil Nowshera. J. American Sci. 6(10):405-407.possibilities in weed control. Herbologia 7(1),9-23.

Fu, P.P., Yang, Y.C., Xia, Q., Chou, M.C., Cui, Y.Y.and Lin, G. (2002): Pyrrolizidine alkaloids tumorigenic components in Chinese herbal medicines and dietary supplements, Journal of Food and Drug Analysis, Vol. 10, No. 4, , pp. 198-211.

Halder, J. and Patra, A.K. (2007): Effect of 113. chemical weed-control methods on roduction of transplanted rice. Indian $\mathrm{J}$. Agron. 52(2):111-

Ita, S.O., Etim, O.E., Ben, E.E. and Ekpo, O.F. (2007): Haemato-poietic properties of thanolic leaf extract of Ageratum conyzoides (Goatweed) in albino rats. Nigerian Journal of Physiology and Science, 22: 83-87.

Ita, S. O., Akpanyung, E. O., Umoh, B.I., Ben E. E. and Ukafia, S.O. (2009): Acetaminophen Induced Hepatic Toxicity: Protective Role of Ageratum conyzoides. Pakistan Journal of Nutrition, 8: 928932.

Jagetia, G.C., Shirwaikar, A., Rao, S.K. and Bhilegaonkar, P.M. (2003): Evaluation of the radioprotective effect of Ageratum conyzoides Linn extract in mice exposed 
to different doses of gamma radiation. Journal of Pharmacy and Pharmacology, 55: 1151-1158.

Jesse, L.C., Moloney, K. A. and Obrycki, J. $\mathrm{J}(2006)$ : Insect visitors of invasive plant Rosa multiflora (Rosaceae), In Lowa, USA. Weed Biology and Management. 6: 235340.

Juliana, H.C. N., Edlayne, G., Silvia, R. G. Roseane, F., Marcia, O.M. M. and Joana D. F. (2010): Ageratum conyzoides essential oil as aflatoxin suppressor of Aspergillus flavus. International Journal of Food Microbiology, 137:55-60.

Kadam Madhuri and Khandekar, V. P. (2009): Weed population associated with dicot crops around Satara. Bioinfolet 6 (1): 7476.

Kaur, N., Dhuna, V., Kamboj, S.S., Agrewala, J.N., Singh, J. (2006): A novel antiproliferative and antifungal lectin from Amaranthus viridis Linn seeds. Protein Pept. Lett., 13(9): 897-905.

Kohli R.K., Batish D.R., Singh H.P. and Dogra, K.S. (2009): Ecological Status of some invasive plants of Shiwalik Himalayas in North-western India. In: Invasive Plants and Forest Ecosystem (Eds. Kohli,R., Jose, S., Batish, D. and H.P. Singh.) CRC/Taylor Press. Netherlands., pp. 143156.
Kremer, R. J. and Kennedy, A. C. (1996): Rhizobacteria as biocontrol agents of weeds. Weed Technol. 10:601-609.

Mahanta, J. J., Chutia, M. and Sharma, T.C. (2007): Study on weed flora and their influence on Patchouli (Pogostemon cablin Benth.) oil and patchoulol. J. Plant Sci., 96-101.

Mann, A., Gbate, M., Umar, A.N. (2003): Sida acuta subspecie acuta. Medicinal and economic plant of Nupe land, Jube Evans Books and Publication, p. 241.

Memon, R.A.; Bhatti, G.R. Khalid, S. (2003): Pakistan Journal of Weed Science Research (Pakistan). 9: 99.

Mishra, J. S. and Singh, V. P. (2003): Interference of Euphorbia geniculata in soybean-chickpea cropping system. Indian J. Weed Sci. 35: 225- 227.

Misra, R. (1968): Cf. Fundamentals Of Ecology, M.C. Dash; Tata McGrew-Hili Publishing Company Ltd.; New Delhi.

Morale, C. L. and Aizen, M. A. (2006): Invasive mutualism and the structure of plant pollinators interaction in temperate forest of north-west Patagonia, Argentina. J. Ecology. 94: 171-180. 
Table 1: List of dominant weed species along with their Families and Botanical names

\begin{tabular}{|c|c|c|c|}
\hline Sr.No. & Weed & Family & Freq-uency(\%) \\
\hline 1 & Parthenium hysterophorus & Asteraceae & 58.14 \\
\hline 2 & Ageratum conyzoides & Asteraceae & 49.53 \\
\hline 3 & Euphorbia geniculate & Euphorbiaceae & 45.35 \\
\hline 4 & Sida acuta Burm. & Malvaceae & 38.40 \\
\hline 5 & Alternanthera sessilis & Amaranthaceae & 35.72 \\
\hline 6 & Cynodon dactylon (L.)Pers & Poaceae & 33.12 \\
\hline 7 & Euphorbia hirta L. & Euphorbiaceae & 31.20 \\
\hline 8 & Oxalis corniculata $L$. & Oxalidaceae & 25.45 \\
\hline 9 & Amaranthus viridis & Amaranthaceae & 23.56 \\
\hline 10 & Launaea procumbens & Asteraceae & 20.70 \\
\hline 11 & Dinebra retroflexa & Poaceae & 19.68 \\
\hline 12 & Dinebra spp & Poaceae & 18.90 \\
\hline 13 & Euphorbia prostrate Aiton. & Euphorbiaceae & 18.45 \\
\hline 14 & Chenopodium album & Chenopodiaceae & 17.00 \\
\hline 15 & Portulaca oleracea $L$ & Portulacaceae & 15.50 \\
\hline 16 & Tridax procumbens $L$ & Asteraceae & 14.26 \\
\hline 17 & Amaranthus spinosus & Amaranthaceae & 12.15 \\
\hline 18 & Paspalum distichum Acut. & Poaceae & 11.50 \\
\hline 19 & Euphorbia rosea & Euphorbiaceae & 10.20 \\
\hline 20 & Cyperus rotundus $L$. & Cyperaceae & 9.56 \\
\hline
\end{tabular}

